\title{
Self-limited autoimmune disease related to transient donor $B$ cell activation in mice neonatally injected with semi-allogeneic $F_{1}$ cells
}

\author{
Marcial de la Hera', Antonio de la Hera', Angeles Ramos, Luis Buelta², \\ Jose Luis Alonso', Vicente Rodriguez-Valverde', and Jesus Merino \\ Immunology, Rheumatology ${ }^{1}$ and Pathology ${ }^{2}$ Units, Hospital 'Marqués de Valdecilla', Unıversıty of \\ Cantabria, Santander, Spain \\ ${ }^{3}$ The Basel Institute for Immunology, Grenzacherstrasse 487, Basel 4058, Switzerland
}

Key words: neonatal tolerance, lupus-like syndrome, allogeneic interactions

\begin{abstract}
BALB/C mice injected at birth with $10^{8}$ semi-allogeneic (C57BL/6 $\times$ BALB.IgH bF $_{1}$ spleen cells develop a lupus-like syndrome In which autoantibodles bear exclusively the donor allotype. We have analyzed the evolution of donor B cell chimerlsm and the autoimmune manifestations during the first year of life in these mice. Antl-DNA, -histone, and -cardlollpin IgG antlbodies as well as circulating immune complexes appeared in the second week of life, reached the highest values around the sixth week, and then progressively dropped to normal values after the sixth month in most mice. The kinetics of the evolution of the autoimmune manifestations, as well as the kinetics of serum donor Ig allotype, were parallel to the kinetics of donor B cell chimerism, which was particularly prominent in the spleens in early weeks of life, and progressively decreased after remission of the autolmmune syndrome. Membrane-proliferative glomerulonephritis, which was followed as the more representative histological abnormality in this model, was particularly evident after 10 weeks of life, but disappeared by the end of the follow-up. Interestingly, when mice with a self-llmited disease were re-injected with $10^{8} F_{1}$ spleen cells i.v., a flare in the serological manifestations was observed. In these re-Injected mice a predominance of anti-DNA, IgG1 antibodles bearing exclusively the donor allotype was also observed, as in the early weeks of life. These results emphasize the central role of donor $B$ cell chimerism in the development and In the self-limitation of the autoimmune disease in parental mice neonatally injected with $F_{1}$ cells and indicate that the capacity to react with $F_{1}$ cells, to generate a renewed burst of symptoms, persists in these mice after the disappearance of autoimmune findings.
\end{abstract}

\section{Introduction}

Although spontaneous models of mouse systemic lupus erythematosus (SLE), such as NZBN, MRL/lpr, or BXSB, have been widely studied $(1,2)$, experimentally-induced models of SLE have received less attention. Recently, it has been reported that $\mathrm{BALB} / \mathrm{C}$ mice injected at birth with semi-allogeneic (C57BL/6 $\times$ BALB.IgH $\left.{ }^{\text {b}}\right) F$, spleen cells develop a SLE-like disease consisting of hypergammaglobulinemia, with production of several autoantibodies, circulating immune complexes (CICs), lymphosplenomegaly, thrombocytopenia, and glomerulonephritis (3). Prevous studies on the immune mechanisms responsible for the autoimmune syndrome observed in mice neonatally Injected with $F_{1}$ cells have demonstrated that autoantibodies are only produced by donor $B$ cells (4) and that host CD4 ${ }^{+}$T cells are necessary for donor $B$ cell activation, whereas donor $C D 4^{+}$ $T$ cells are not $(5-8)$.

In lupus-prone mice, abnormal levels of autoantibodies and $\mathrm{CICs}$ begin to be detectable after 2 months of life and progressively increase, leading in most cases to death due to glomerulonephritis (GMN) $(9-11)$. Murine models of graft versus host disease present a broad range of serological abnormalities, 
varyıng from hypogammaglobulinemia, in close relation to hypoplastic syndrome, to autoimmune manifestations associated with lymphoproliferative and collagen-vascular disease (12). In contrast with classical experimental murine models of autormmune disease, the kinetics of autoantibody production and evolution of GMN, considered as the most representative histological lesion (3), has not been established in this model of SLE-lıke disease.

The aim of this study was to characterize the long-term evolution of the autoantibody pattern and autoimmune lesions developed in mice neonatally injected with $F_{1}$ cells. Considering the central role of donor $B$ cells in this model, we have also analyzed the kinetıcs of donor $\mathrm{T}$ and $\mathrm{B}$ lymphocyte chımerism in different lymphoid organs. Here we present evidence of a progressive decrease of donor $B$ cell chimerism that correlates with the evolution of serum autoantibody titers and the self-limitation of the autoimmune syndrome. In addition, the production of autoantibodies was re-activated by the re-injection of $F_{1} B$ cells into adult neonatally injected mice that had manifested a self-lımited autoımmune disease.

\section{Methods}

Mice

BALB/C and C57BL/6 mice were purchased from Charles River (Spain), Congenıc BALB.Igh ${ }^{b}$ mice $\left(\mathrm{lgCH}_{-1} 1^{\mathrm{b}}\right)$ were kindly provided by the Walter \& Elisa Hall Institute (Melbourne, Australia). (C57BL/6 $\left.\times \mathrm{BALB} \mathrm{IgH}^{\mathrm{b}}\right) \mathrm{F}_{1}$ hybrid mice were produced in our laboratory.

\section{Injection of cells into neonatal mice}

A cell suspension containing $10^{8}$ spleen cells from $2-3$ month old (C57BL/6 $\times$ BALB.IgH $\left.{ }^{\text {}}\right) F_{1}$ hybrid mice was I.p. Injected into newborn BALB/C ( $\left.\operatorname{lgh}^{a}\right)$ mice within $24 \mathrm{~h}$ after birth, as previousty described (5). Control mice were uninjected littermates.

\section{Serum samples}

Ether anesthetized mice were bled by retro-orbital sinus puncture and blood was kept for $90 \mathrm{~min}$ at room temperature to clot. Then, serum was separated by centrifugation at $1500 \mathrm{~g}$ for $10 \mathrm{~m} ı \mathrm{n}$ and stored at $-70^{\circ} \mathrm{C}$ until use.

\section{Determination of $\mathrm{g}$ allotype}

To evaluate the levels of $\operatorname{lgh}^{\mathrm{b}}$ allotype bearing Igs in the serum of $F_{1}$ cell injected mice, a previously described (4) solid-phase ELISA was employed using an alkaline phosphatase (AP) conjugated anti-lgh ${ }^{b}$ allotype antiserum, obtained as previously reported $(13,14)$. Results were expressed in mg-equivalent $/ \mathrm{ml}$ of lgh' bearing $\mathrm{lg}$ from normal C57BL/6 serum.

\section{Solid-phase anti-single-strand (sS) DNA assays}

To measure anti-ssDNA IgG and IgG subclass antibodies, as well as to determine the donor or host Ig allotype of these antibodies, ELISA techniques were employed as described elsewhere (7). Goat anti-mouse $r$-chain specific antibody (Cappel Laboratories, Cochranville, PA) and rabbit anti-mouse IgG subclass-specific antibodies (Biometics Lab., Kensington, MD) were used as AP conjugates. In addition, a mouse mAb specific for IgG2a-lgh ${ }^{b}$ allotype (donated by Dr Van Snick, Ludwig Institute for Cancer
Research, Brussels) as well as anti-lgh ${ }^{a}$ and anti-lgh b allotype antisera, obtained as previously described (7), were conjugated to AP and used in these experiments. Results are expressed in titration units (TU) referred to a standard curve obtaıned by serial dilutions of a serum pool obtained from 6-8 month old MRL Ipr/pr mice, except for anti-ssDNA IgG2a antıbodies or for antissDNA antibodies bearing the $\operatorname{lgh}^{\mathrm{b}}$ donor allotype, where a serum pool obtained from $6-8$ month old male BXSB mice was used.

\section{Anti-histone and anti-cardiolipin antibodies}

An ELISA method was employed, similar to that used for anti-ssDNA antibodies. Polystyrene microtiter plates (Limbro, Flow Lab., McLean, VA) were coated with $50 \mu$ of total histones (Boehringer-Mannheim 223565) diluted at $10 \mu \mathrm{g} / \mathrm{ml}$ in borate buffer saline ( $\mathrm{pH} 8.6)$ or with $50 \mu$ of cardıolıpn (Sigma Chemıcal Co., St Louis, MO) diluted at $10 \mu \mathrm{g} / \mathrm{ml}$ in absolute ethanol The contamination of the histone preparation by DNA was $<1 \%$ as estimated by UV spectrophotometry at $260 \mathrm{~nm}$. Plates with cardiolipin were dried under nitrogen flow. For both assays sera were diluted $1 / 100$ in PBS, $1 \%$ BSA, and $0.05 \%$ Tween-20. The AP conjugate used was a goat anti-mouse $\gamma$-chain specific ant।body $(1 \mu \mathrm{g} / \mathrm{ml})$. Results are expressed in TU referred to a standard curve obtained by serial dilutions of the same serum pool of MRL Ipr/pr mice used for anti-ssDNA antibodies, which showed a strong antibody activity against these antıgens.

\section{CICs}

The levels of $\mathrm{ClCs}$ were determıned by conglutınin binding in solid phase, using an ELISA methodology as previously described (5). Bovine conglutinin was obtained from normal adult bovine serum, according to Marre et al. (15). Results are expressed in $\mu \mathrm{g}$-equivalent by reference to a standard curve obtained by serial dilutions of heat aggregated mouse IgG, previously incubated for $45 \mathrm{~min}$ at $37^{\circ} \mathrm{C}$ with fresh normal mouse serum as a source of complement.

\section{Kidney studies}

Kidneys previously fixed in $10 \%$ formaldehyde were embedded in paraffin and $3 \mu \mathrm{m}$ sections were processed with hematoxylin eosın stain, perıodıc acıd-Schift stain, and silver-metenamın impregnation, according to standard methods (16). Tissue binding of $\mathrm{IgM}, \lg$ subclasses, and $\mathrm{C} 3$ was assessed by direct immunofluorescence on kıdney cryocut sections $(4 \mu \mathrm{m})$ using fluoresceinated rabbit anti-mouse IgM (Cappel) or a rabbit ant-mouse IgG subclass specific antiserum (Southern Biotechnology Associates, Birmingham, AL). The presence of C3 was detected wth a rabbyt anti-rat C3 antibody, cross-reactive with mouse C3 (Cappel).

\section{Flow cytometry analysis}

Cell frequencies were analyzed by flow cytometry using a FACScan flow cytometer (Becton-Dickinson, Mountain View, CA) with a Consort-30 (Hewiett-Packard 9000) computer set-up. The following mAbs were used: RA3-2C2 (rat IgM anti-mouse B220) (17), Bet-2 (rat IgM anti-mouse IgG1) (18), MB 86 (rat IgG anti-mouse $\left.\lg M^{\natural}\right)(19)$, and $\lg (5 b) 6.3$ (mouse $\lg G 1$ anti-mouse $\lg \mathrm{D}^{\mathrm{g}}$ ) (20). A $50 \mu \mathrm{l}$ atiquot of a previously determined optimal dilution of these mAbs, conjugated to FITC or biotin, was incubated for $30 \mathrm{~min}$ at $0^{\circ} \mathrm{C}$ with $5 \times 10^{5}$ viable cells, washed 
twice, and, on those biotinylated antibodies, the avidinphycoerythrin complex was added.

\section{Determination of $\mathrm{g} g$ allotype on culture supernatants}

Spleen cells $\left(10^{5}\right)$ from 50 week old neonatally injected mice were cultured in polystyrene plates with lipopolysaccharide (LPS) (25 $\mu \mathrm{g} / \mathrm{ml}$ ) for 5 days. Spleen cells from normal BALB/c mice were also pulsed with LPS and used as controls. The presence of IgM bearing the $\operatorname{lgh}^{\mathrm{b}}$ allotype was analyzed using solid-phase ELISA methodology. Briefly, plates were coated with the MB.86 anti- $\mu^{\mathrm{b}}$ IgG mAb $(10 \mu \mathrm{g} / \mathrm{ml})(19)$. Then, $50 \mu \mathrm{l}$ of undiluted culture supernatant was added to the wells and incubated at room temperature for $2 \mathrm{~h}$. A polyclonal goat anti-mouse $\operatorname{lgM}(1 \mu \mathrm{g} / \mathrm{ml})$ (Southern Biotechnology) was used as the AP conjugate. In order to exclude rheumatoid factor activity, subsequent to LPS stımulation, microtiter plates were coated with similar amounts of an irrelevant $\mathrm{mAB}$, instead of anti- $\mu^{\mathrm{b}} \operatorname{lgG} \mathrm{mAb}$

\section{Results}

\section{Experimental design}

To study the kinetics of autoantibody production and kıdney lesions in parental mice neonatally injected with $F_{1}$ cells, $50 \mathrm{BALB} / \mathrm{c}$ mice, injected at birth with $10^{8}$ (C57BL $6 \times$ BALB.lg $\mathrm{H}^{\text {b) }} \mathrm{F}_{1}$ spleen cells, were bled weekly up to the third week and then every 3-4 weeks until the 50th week of age. Serum samples were tested for the presence of lgs bearing the donor Igh ${ }^{\circ}$ allotype, anti-DNA, anti-histones, and anti-cardiolipin IgG antibodies. The levels of $\mathrm{CICs}$ were also analyzed. At $1.2,4,10,15,27$, and 50 weeks of age, four to seven neonatally injected mice were randomly killed for sequential anatomopathological kidney studies. Single cell suspensions of thymus, spleen, and lymph nodes were obtained at 4, 10 , 16,27 , and 50 weeks of age for flow cytometry analysis. Age-matched uninjected BALB/C mice were used as controls.

Transient donor $\mathrm{Ig}$ and autoantibody production in neonatally injected mice

Igs bearing the donor Igh ${ }^{b}$ allotype were detected in 47 out of 50 neonatally injected mice. Since the presence of donor Igs widely correlates with an effective induction of tolerance, in terms of absence of allo-specific cytotoxic T cell activity (4), in this study we analyzed the 47 mice in which donor lgs were demonstrated. The highest levels of donor Igs in these mice were found in the first 11 weeks of age and then a progressive decrease in their titers was observed. At 50 weeks of age, donor lgs were detectable only in three out of 13 mice and their levels were very low (Fig. 1a).

We next explored the kinetics of autoantibody production. AntiDNA IgG antibodies were demonstrated in $F_{1}$ cell injected BALB/C mice at 1 (25\% of animals) and $2(100 \%)$ weeks of age, reaching the highest titers at 6 weeks in most mice (Fig. 1b). Thereafter, a sharp decrease in the titers of anti-ssDNA antubodies was observed between 8 and 11 weeks of age. Most mice (15 out of 25) reached normal values before the sixth month of age and only one out of 13 injected mice showed very low titers of anti-DNA IgG antibodies at 50 weeks.

In order to evaluate the origin and nature of anti-DNA antibodies in those neonatally injected mice in which these
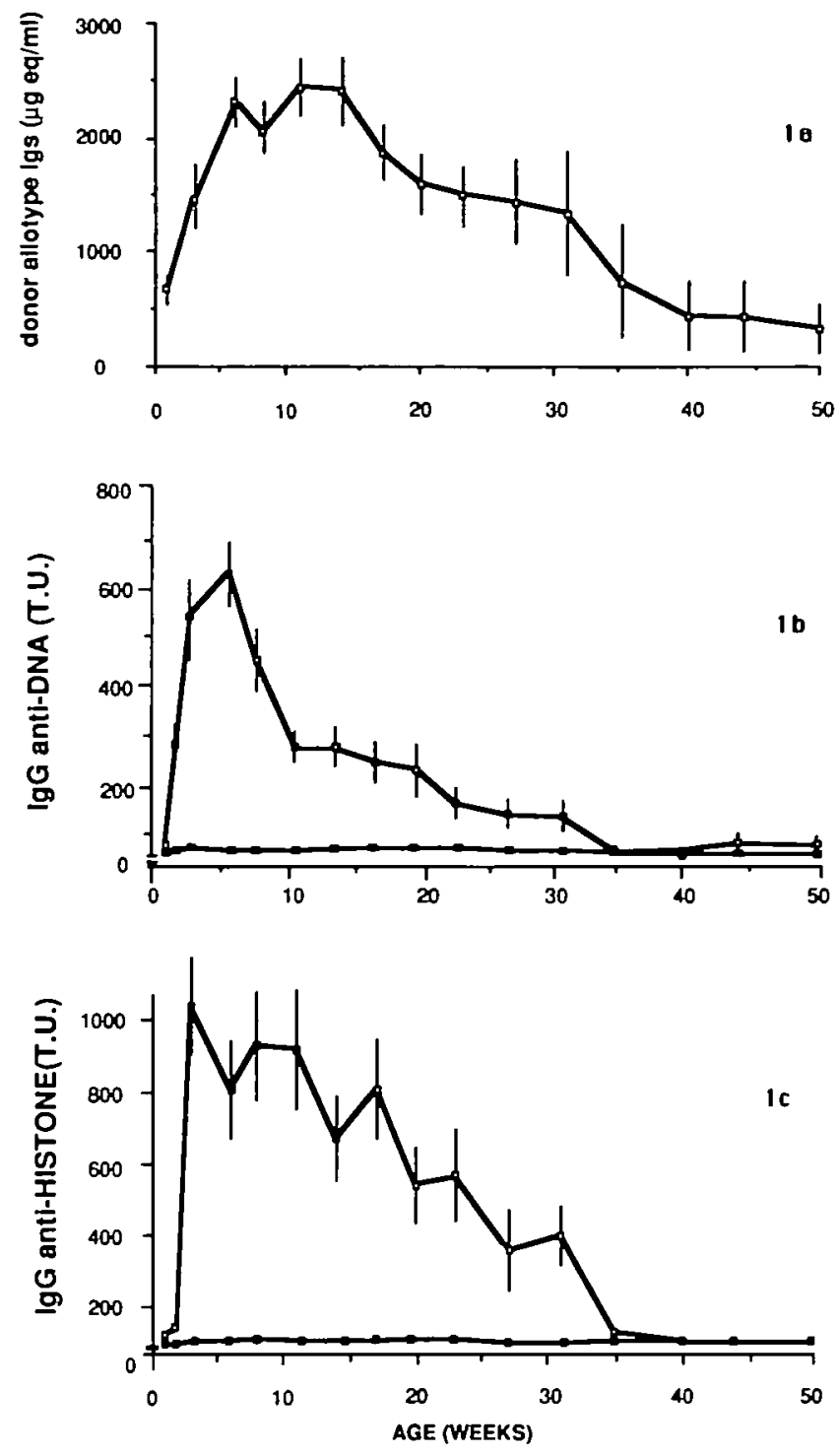

Fig. 1. Follow-up of serum levets of donor allotype lgs (a), anti-ssDNA IgG antibody (b), and anti-histone IgG antibodies (c) in BALB/c mice injected at birth with $10^{8}$ (C57BL6 $\times$ BALB. $\left.\lg H^{6}\right) F_{1}$ spleen cells (open squares) Uninjected BALB/c mice were used as controls (closed squares). Results are expressed in TU for anti-DNA and anti-histone antibodies. Donor allotype is expressed in $\mathrm{mg}$-equivalent $/ \mathrm{ml}$ of equivalent Igh $\mathrm{h}^{\mathrm{b}}$-beaning IgG from normal $\mathrm{C57BL} 6$ serum. SEMs are represented.

antıbodies remained elevated after 20 weeks, their allotype and IgG isotypes were analyzed. The data obtained showed that anti-DNA antibodies in these mice bore only the lghb donor allotype, but not the $\operatorname{lgh}^{a}$ host $\lg$ allotype, indicating their exclusive donor $B$ cell origin (Fig. 2). Furthermore, they exhibit predominantly the $\lg \mathrm{G} 1$ isotype as observed in the early stages of the autoimmune syndrome (4) (Fig. 3).

The evolution of anti-histone lgG antibodies was also studied. Its profile was similar to that of anti-DNA IgG antibodies (Fig. 1c). The highest levels were observed at 3 weeks; thereafter, the titers of these antibodies decreased, reaching normal values 


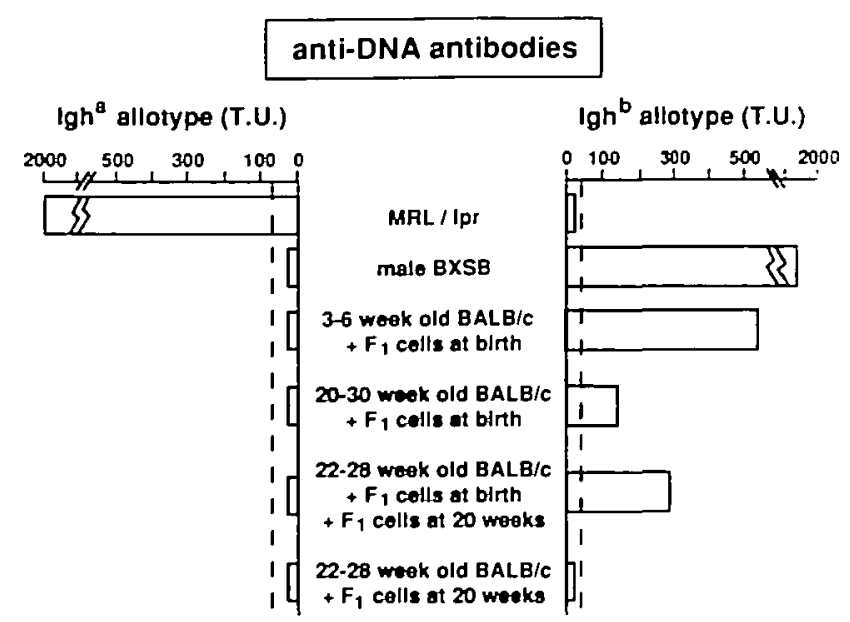

Fig. 2. Serum levels of ant1-DNA antbbodies bearing the lgh ${ }^{\mathrm{a}}$ allotype (left) or the $\operatorname{lgh}^{\mathrm{b}}$ allotype (nght). BALB/c mice (Igh a allotype), injected at birth with $10^{8}$ (C57BL6 $\times$ BALB IgH $^{b}$ F $_{1}$ (Igh ${ }^{6 / b}$ allotype) spleen cells, were sequentially bled and ant-DNA was measured in serum $A$ group of these mice, in which anti-DNA antibodies and CICs dropped to normal values before 20 weeks of age were then i.v re-injected with $10^{8}$ $\left(\mathrm{C} 57 \mathrm{BL} / 6 \times \mathrm{BALB} \mathrm{gh} \mathrm{H}^{\mathrm{b}} \mathrm{F}_{1}\right.$ spleen cells. Mice, uninjected at burth, that received I $v$. Injection of $10^{8}\left(\mathrm{C} 57 \mathrm{BL} / 6 \times \mathrm{BALB}^{2} \mathrm{HH}^{6}\right) \mathrm{F}_{1}$ spleen cells at 20 weeks of age served as control for this last group. ELISA results were obtained on sera selected on the basis of the presence of anti-DNA IgG antibodies, from the following groups of mice (1) $3-6$ week old injected mice; (2) 20-30 week old injected mice with persistent hıgh titers of ant-DNA antibodies at this age, and (3) 20 - 30 week old mice re-ınjected with $F_{1}$ cells after self-lımitation of their primary autommune syndrome. Results are expressed in TU and represent the mean values obtained in 15-20 sera per group. Discontinuous lines represent means $+3 \mathrm{SD}$ of the values obtained in age-matched uninjected BALB/c control mice.

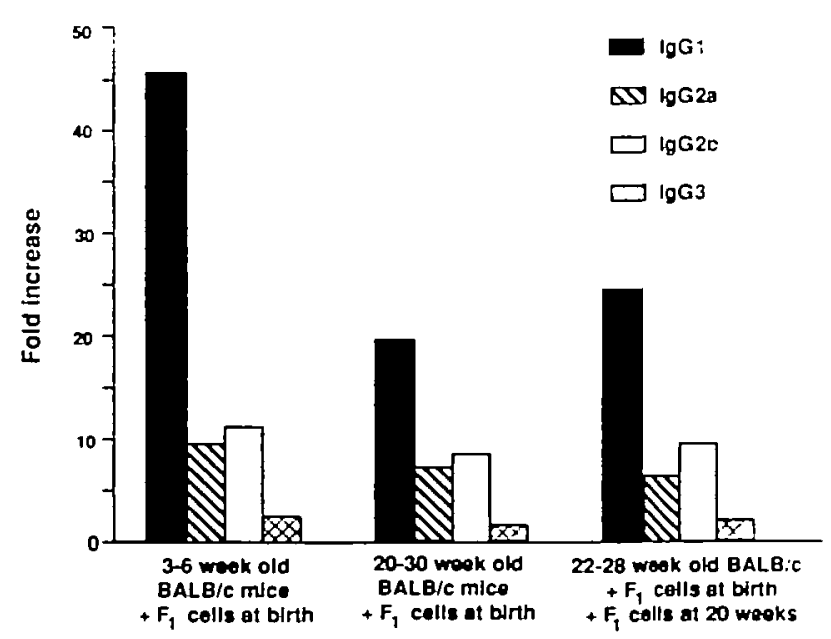

Fig. 3. Comparative levels of anti-DNA IgG subclasses in three different groups of sera from BALB/c mice injected at burth with $10^{8}$ (C57BL/6 $\times$ BALB.IgH $) F_{1}$ spleen cells: (1) sera from $3-6$ week old injected mice, (2) sera from 20-30 week old injected mice with persistent high titers of ant-DNA antibodies at this age; and (3) sera from 20-30 week ofd mice re-injected with $F_{1}$ cells after self-limitation of their primary autoimmune syndrome. Sera from $8-12$ age-matched uninjected BALB/C mice served as control in each group. Values represent the fold increase of the titers, expressed in TU, as compared with the controls and express the mean values of $12-15$ sera per group.
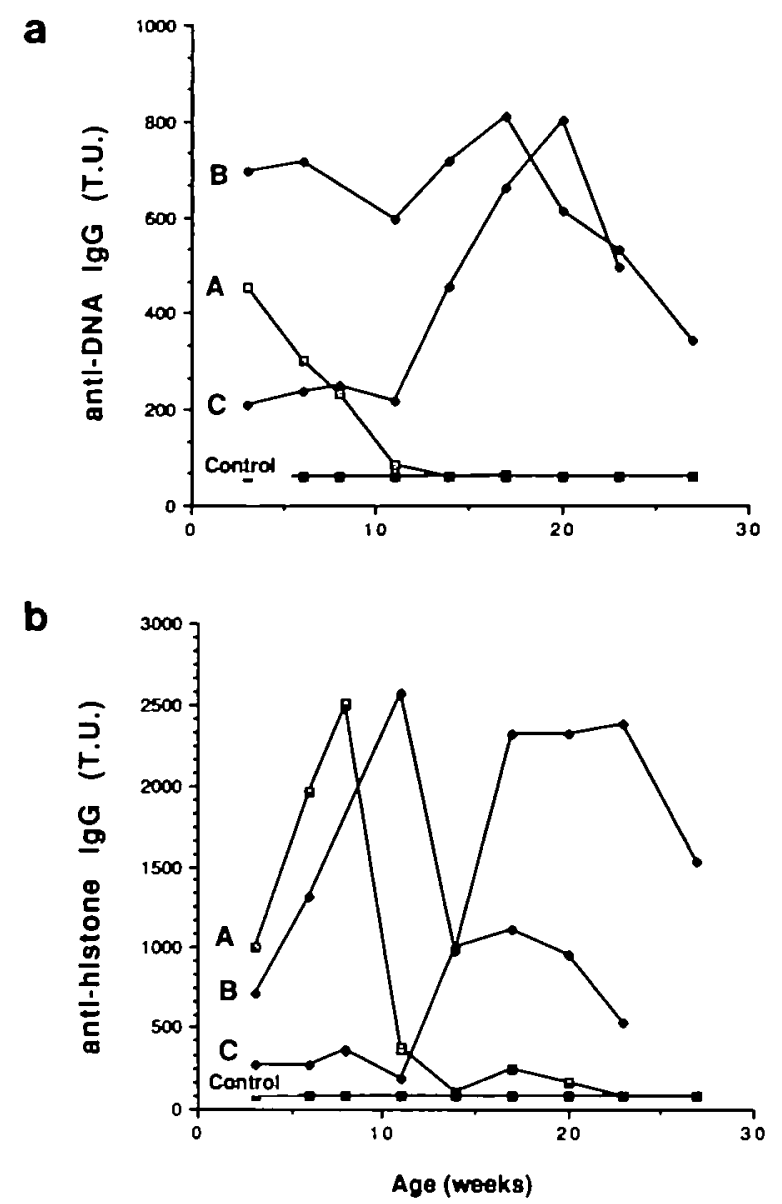

Fig. 4. Examples of individual evolutions of three $B A L B / c$ mice $(A-C)$ injected at birth with $10^{8}\left(\mathrm{C} 57 \mathrm{BL} / 6 \times\right.$ BALB IgH $6 \mathrm{H}^{\mathrm{b}} \mathrm{F}_{1}$ spleen cells Results are expressed in TU for anti-DNA (a) and anti-histone IgG (b) antibodies.

at 30 weeks of age in most mice. Furthermore, the titers of anti-cardiolipin IgG antibodies and $\mathrm{CICs}$ showed a similar evolution to the anti-DNA and anti-histone antibodies (data not shown).

Regarding the individual evolution of autoantibodies and $\mathrm{CICs}$, two kinds of kinetics could be observed. (1) In most mice (20/32) autoantibodies had a similar evolution to that described for the whole group, with early sustained self-limitation of serological markers during the first months of life, as illustrated in mouse A of $\mathrm{Fig}$. 4(a and $\mathrm{b})$. (2) In the remaining mice, the kinetics were diverse, with long-lasting autoantibodies and/or fluctuations in the levels of the different serological markers during the study, reaching normal titers several weeks later than in the previous group. Two representative examples of these alternative patterns are shown in mice $B$ and $C$ of Fig. $4(a$ and $b)$.

\section{Mortality rate and immunopathological alteratıons in kidneys of neonatally injected mice}

We did not observe any significant difference in mortality rates between injected and control mice during the length of the study. Only three injected mice died spontaneously as a consequence of the development of a non-Hodgkin polymorphic lymphoma. In the kidneys, deposits of $\operatorname{lgG}, \lg M$, and $C 3$ were seen at 2 
Table 1. Kinetic study of Igs and $\mathrm{C} 3$ deposits in the glomeruli of injected mice

\begin{tabular}{|c|c|c|c|c|c|c|}
\hline $\begin{array}{l}\text { Immunofluorescence } \\
\text { staıning }\end{array}$ & $\begin{array}{l}\text { 1st week } \\
(n=4)\end{array}$ & $\begin{array}{l}\text { 2nd week } \\
(n=3)\end{array}$ & $\begin{array}{l}\text { 4th week } \\
(n=2)\end{array}$ & $\begin{array}{l}10 \text { th week } \\
(n=4)\end{array}$ & $\begin{array}{l}27 \text { th week } \\
(n=4)\end{array}$ & $\begin{array}{l}\text { 50th week } \\
(n=6)\end{array}$ \\
\hline $\lg G$ & 0 & + & ++ & +++ & $+t+t$ & + \\
\hline $\lg G 1$ & 0 & + & + & $+t$ & +++ & + \\
\hline $\lg G 2 b$ & 0 & 0 & +- & + & + & + \\
\hline $\lg 33$ & 0 & 0 & 0 & + & + & 0 \\
\hline $\lg M$ & 0 & ++ & + & ++ & $++t$ & $+1++$ \\
\hline $\mathrm{C} 3$ & 0 & + & ++ & ++ & +++ & + \\
\hline Light microscopy & $N$ & $N$ & $\dot{N}$ & mGNM & $\mathrm{aGNM}^{\mathrm{d}}$ & $\mathrm{N}^{\mathrm{C}}$ \\
\hline
\end{tabular}

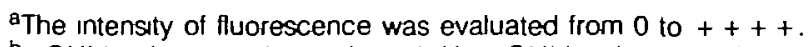

b mGNM, minımum glomerulonephritis, aGNM, advanced glomerulonephritis, N, absence of pathological lesions

cOne out of six mice analyzed had GMN.

II should be noted that, due to random selection, three out of six mice studied at 27 weeks still had active autormmune disease, with increased titers of autoantibodies and CICs.

weeks of age in the subendothelıal capillary loops and in the mesangium of injected mice. A progressive increase in granular deposits was observed until the 27 th week. In this respect, it should be noted that three out of six mice killed at the 27th week had active autoimmune disease with abnormal levels of autoantibodies and CICs. Typical histological features of diffuse proliferatıve GMN, with thickenıng of capillary loops, widēnıng of the matrix, and discrete increase in the number of mesangial cells, were only seen after 10 weeks of age in these mice. Thereafter, at the end of the follow-up, no significant histological lesions were observed in kidneys by conventional microscopy, in spite of the persistence of weak fluorescent deposits of lgG in the mesangium (Table 1).

Kinetics of donor $T$ and $B$ cell chimerism in lymphord organs The frequencies of $T$ and $B$ cells of donor orıgin were studied in injected mice by immunofluorescence and flow cytometry analysis in single cell suspensions of thymus, spleen, and lymph nodes obtained at $4,10,16,27$, and 50 weeks of age

In these $F_{1}$ cell injected mice the cell chimerism was more evident and persistent in the spleen than in the thymus or lymph nodes. Significant proportions of $T$ and $B$ cells of donor origin were demonstrated in the spleen of injected mice in the early weeks of age, reaching the highest values in the fourth week (Table 2 and Fig. 5). Thereafter, a sharp decrease in the frequency of donor T lymphocytes was seen, being undetectable after 13 weeks of age, though a low number of donor $B$ cells was still detected at 27 weeks of age (Table 2). No evidence of donor B cells was lound in any of the spleen samples analyzed at 50 weeks. However, when spleen cells from these 50 week old $F_{1}$ cell injected mice were cultured in vitro for 5 days with LPS, Igs bearing the donor $\operatorname{lgh}^{\mathbf{b}}$ allotype were demonstrated in the culture supernatants (data not shown). These data are consistent with a steep decrease in donor B cell chimerism in tolerant mice, with a small number of $B$ cells persisting at very low levels after the first year of life.

Evidence of $T$ cell chımerism was found in lymph nodes of neonatally injected mice at 4 weeks of age (10\% of total lymphosd cells) but not later ( $<1 \%$ after 10 weeks of age). The smal proportion of $B$ cells in these organs did not allow an accurate determination of the frequency of cells bearıng surface lgs with the donor allotype. With regard to the thymus, none of the
Table 2. Flow cytometry analysis of spleen cells (FACScan I),

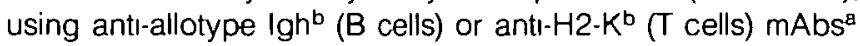

\begin{tabular}{llllll}
\hline & \multicolumn{2}{l}{ Age (weeks) } & & & \\
\cline { 2 - 6 } & 4 & 10 & 15 & 27 & 50 \\
\hline B cells & & & & & \\
donor & 28 & 12 & 35 & 2.2 & $<1$ \\
host & 33 & 55 & 58.5 & 62.8 & 62 \\
Total & 61 & 67 & 62 & 65 & 62 \\
T cells & & & & & \\
donor & 9 & 3 & $<1$ & ND & ND \\
host & 24 & 28 & 29 & ND & ND \\
Total & 33 & 31 & 29 & ND & ND \\
\hline
\end{tabular}

aThe mean of postive cells (\%) from three to seven mice per group is expressed.

samples analyzed after the third week of life showed a significant amount of T lymphocytes bearing donor $\mathrm{H}-2^{\mathrm{b}}$ surface antigens.

Re-injection of $F_{1}$ cells in neonatally injected mice re-activates the autoimmune syndrome

The data presented here suggest that a reduction in the number of donor B cells could be responsible for the self-limitation of the autoimmune syndrome observed in most of these mice. In order to evaluate this hypothesis, 20 week old BALB/C mice, injected at birth with $10^{8}$ (C57BL/6 $\times$ BALB.lgH $\left.H^{b}\right) F_{1}$ spleen cells, were followed up to the time that the levels of anti-DNA IgG antibodies and CICs dropped to normal. Then, in three separate experiments, groups of four or five mice were injected i.v. with $10^{8}$ spleen cells from (C57BL6 6 BALB.lghb) $F_{1}$ mice. As controls, age matched neonatally uninjected $B A L B / C$ mice were also i.v. injected with $10^{8} \mathrm{~F}_{1}$ spleen cells.

In 10 out of 14 re-injected mice, a new increase in the levels of donor Igs, and in the titers of anti-DNA antibodies (Fig. 6) and $\mathrm{ClCs}$ was observed. In the remaining four mice (which are not represented in Fig. 6) none of these parameters were modified after re-injection. The evolution of CICs as well as the levels of Igs with the donor allotype after re-injection of $F_{1}$ spleen cells in these mice was similar to that observed for anti-DNA IgG antibodies (data not shown). By contrast, controf BALB/c mice 


\section{Self-limited autormmunity in neonatally injected mice}

uninjected at birth, which received $F_{1}$ spleen cells at 20 weeks of age, failed to develop significant levels of anti-DNA antıbodies (Fig. 6) and CICs.

The anti-DNA IgG antibodies observed in these $F_{1}$ cell re-injected $B A L B / C$ mice had the same isotypic pattern (predominance of $\operatorname{lgG} 1$ ) found in the early and late stages of the autoimmune syndrome (Fig. 3). In order to evaluate the origin of the autoantibodies detected in these $F_{1}$ cell re-injected $\mathrm{BALB} / \mathrm{c}$ mice, the Ig allotype of the anti-DNA antibodies was also studied. As represented in Fig. 2, only lgs bearing the $\operatorname{lgh}^{\mathrm{b}}$ donor allotype, but not those bearing the Igha host allotype, showed anti-DNA reactivity.

By immunofluorescence, dense IgG and IgM deposits were observed in the renal glomeruli of $F_{1}$ cell re-injected BALB/C mice showing a burst in the autoantibody titers. Moderate IgG and $\operatorname{lgM}$ deposits were also seen in kıdneys from mice in which re-injection of $F_{1}$ cells does not reinduce autoantibody production. By contrast, no Ig deposits were observed in renal glomerulı of $B A L B / c$ control mice that received a first injection of $F_{1}$ cells at 20 weeks of age.

\section{Discussion}

We have shown that the injection of semı-allogeneic spleen cells from (C57BL $6 \times$ BALB.IgH $^{\text {}}$ ) F, mice into parental newborn $B A L B / c$ mice results in a self-lımited autoımmune disease in whıch a decrease in donor $B$ cell chimerism is closely related to the normalization of the serological autoimmune manifestations and precedes by several months the clearance of glomerular Ig deposits. Moreover, we have also shown that re-injection of $F_{1}$ donor B cells in adult neonatally injected mice has a boosting effect on the production of autoantibodies.

In this model, host $\mathrm{CD}^{+}$helper $\mathrm{T}$ cells that recognize allogeneic class II molecules are known to be necessary for the activation of autoreactive donor $B$ cells $(7,8,21)$, which are uniquely responsible for the production of autoantibodies (4). These donor $B$ cells seem to be polyclonally activated through an allogeneic interaction, as demonstrated in experiments using hapten-carrier immunizations (4). A similar mechanism could be claımed in experiments in which mouse helper T cells, specific for $B$ cell surface antigens, polyclonally activate in vitro a large proportion of peripheral $B$ cells independently of their actual antigen specificities (22).

As compared with other experimental models of SLE, our results show two distinctive features in the autoimmune manifestations of these chimeric mice: (1) the production of autoantibodies starts very early in life and uses preferentially the IgG1 isotype, and (2) the syndrome is not life threatening due to spontaneous abrogation of the serological and histological manifestations of the disease in adult life. These data should shed some light on the kinetics of cellular interactions involved in both the triggering and the self-limitation of autoantibody production in neonatally injected mice.

With regard to the triggering of the autoimmune syndrome, there are three findings that merit special consideration. Firstly, the autoantibody response uses predominantly the $T$ helperdependent IgG1 isotype as early as the second week of life and maintains this predominance in later stages. This observation indicates that helper $\mathbf{T}$ cells from neonatally injected mice are able to activate the $\mathrm{lg}$ isotype switch in donor $\mathrm{B}$ cells very early

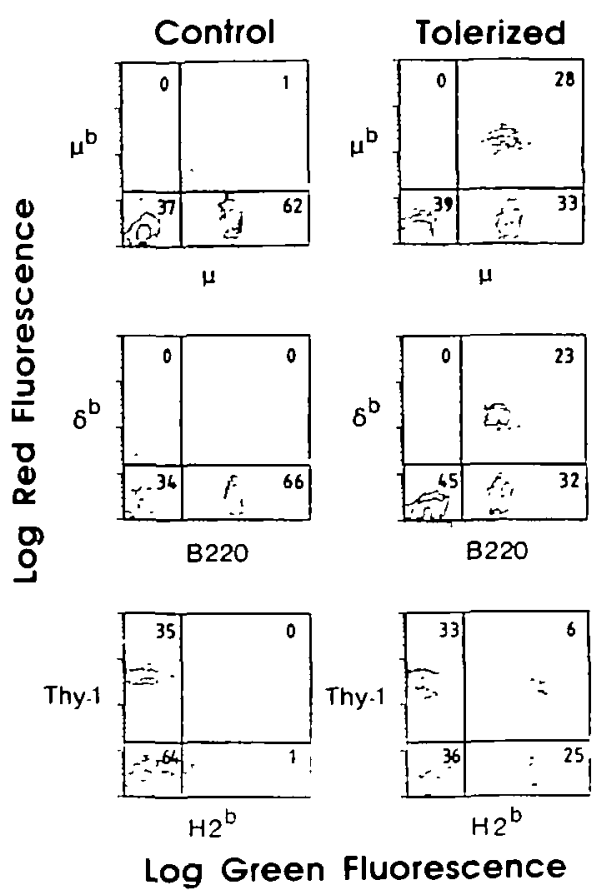

Fig. 5. Phenotypic analysis of spleen cells from a representative 4 week old BALB/C mouse neonatally injected with $10^{8}$ (C57BL/6 $\times$ BALB.Ig $\left.H^{\text {b }}\right) F_{1}$ spleen cells (right) or uninjected BALB/c mice as controls (left). Cells were stanned with fluorescein-labeled anti-lgM (Bet 2), antiB220 (RA3-2C2), and anti-H-2 ${ }^{b}(28-13.35)$ antıbodies, or phycoerythrinconjugated anti-lgM ${ }^{b}$ (MB 86), anti-lgD ${ }^{b}$ (Ig5b 6.3), and anti-Thy-1 (30-H.12) antibodies as depicted Two-color analysis was performed on a FACScan flow cytometer. Data were acquired using FACScan Research software. Contour plots were generated using C30 software (Becton-Dickinson). Background levels for green and red fluorescence are indrated by contınuous lines. Fluorescence intensity is represented in logarithmic units. Percentages of cells are indicated in each quadrant.

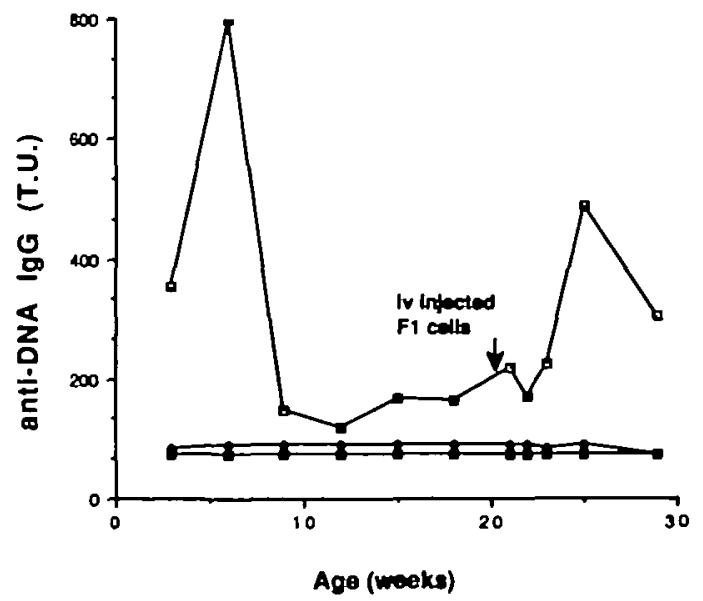

Fig. 6. BALB/C mice, i.p. injected at birth with $10^{8}$ (C57BL/6 $\times$ BALB. $\left.\lg H^{b}\right) F_{1}$ spteen cells were i.v. reinjected at 20 weeks of age with the same dose of $F_{1}$ spleen cells $(\square)$. As controls, unmanipulated $B A L B / c$ mice ( $\square$ ) and BALB/c mice uninjected at birth but i.v. injected at 20 weeks of age with $10^{8}$ (C57BL $6 \times$ BALB.lgHb) $F_{1}$ spleen cells ( $\bullet$ were used. The values of IgG anti-DNA antibodies are expressed in titrathon units and represent the mean values of 10 mice per group 
in life and that a similar kind of cellular cooperation is maintained through the length of the autoimmune syndrome. This fact seems to be closely related with the pattern of lymphokine production in parental mice neonatally injected with $F_{1}$ cells In this context, it has recently been found that a 10 -fold increase frequency of IL-4 producing donor-allospecific T helper cells occurs in neonatally injected mice, as compared with unmanipulated mice (24; M. de la Hera et al., manuscript in preparation). Moreover, treatment with anti-IL-4 mAb strongly decreased autoimmune manifestations in these mice and cause a marked abrogation of IgG1 autoantıbody production (24).

Secondly, we show here that exclusively donor B cells appear to be involved in the production of autoantibodies in three different situations early and late stages of the autoimmune disease, and after re-injection of $F_{1}$ cells in previously autoimmune mice. These findings Indicate that the host $T$ helper activity on donor $B$ cells is very selective and does not involve autoreactive donor $B$ cells through a putative bystander help effect, as seems to occur in some in vitro interactions (25). Our results are in agreement with those of others $(22,26)$ indicating that in vivo interactions show no bystander effects, requiring a direct recognition of antigen by helper T cells on the surface of $B$ cells.

Thirdly, autoantibodies observed in neonatally injected mice show marked differences from so-called natural autoantibodies. Indeed, in addition to the IgG1 predominance, autoantibodies of $F_{1}$ cell injected mice are not highly cross-reactive with autoantigens (27, our unpublished observations), whereas autoantbody repertores of naturally activated autoreactive $B$ cells use predominantly the IgM isotype and show characteristic cross-reactive specificities $(28,29)$.

With respect to the spontaneous remission of the autoimmune syndrome in adult life, we show direct evidence for the existence of donor B cell chımerısm in this model, which drops dramatically with ageing. We also show that the progressive decrease in the number of donor B cells in host lymphoid organs correlates well with the disappearance of autoantibody production. Interestingly enough, a new increase in autoantibody tters was observed upon re-injection of $F_{1} B$ cells in some mice having a self-limitation of their autoimmune syndrome. This effects seems to be due to a donor $\mathrm{B}$ cell activation of similar characteristics to that observed in neonatal mice, as suggested by the predominance of IgG1 autoantibodies and similar autoantibody kınetics. It should be noted, however, that a burst of autoantıbody production in adult life only occurred in previously $F_{1}$ cell injected mice. All these data strongly support the idea that the transient nature of the $B$ cell chımerism is a major mechanism for the self-limitation of the autoimmune disease.

Nevertheless, the results presented here do not exclude the possibility that other regulatory mechanisms could play a role in the self-limitation of the disease In fact, after LPS stimulation of spleen cells, antibodies produced by donor B cells were demonstrated at 50 weeks of age, indicating that some donor $B$ cells are able to persist in $F_{1}$ cell injected mice without evidence of autoimmunity. This finding suggests that additional regulatory mechanisms might be involved in the autonomous limitation of the disease. Moreover, the observation that, contrary to most neonatally injected mice, some anımals exhibit long lasting autoimmunity, could suggest that individual variations in such a putative control mechanism can allow different patterns of autoimmune disease in neonatally injected mice. In this respect,
$\mathrm{CD8}^{+}$cytotoxic/suppressor $T$ cells do not seem to play an essential role in this model, because the in vivo depletion of this T cell subset in neonatally injected mice was unable to modify the evolution of the autoimmune syndrome or to induce a relapse of the disease in mice with a previous self-limıtation of their autoimmune manifestations (6).

Moreover, the establishment of an active suppressor mechanism seems improbable in view of the rapid rise of autoantibodies and $\mathrm{CICs}$ after re-injection of $F_{1} B$ cells.

An alternative mechanism of functional inactivation (clonal anergy) could be claimed to explain the self-limitation of the autoimmune syndrome. Thus, it has recently been observed that occupation of the $T$ cell receptor can be followed by a signal to down-regulate further antigen responsiveness (30). This mechanism has also been involved in the Induction of neonatal tolerance to some superantigens, such as Mls $-1^{\mathrm{B}}$ determinants (31). However, the observation that re-injected donor B cells suffer an allogeneic stimulation, similar to that observed in neonates, indicates that this knd of regulation does not occur in our parental neonatally injected mice. The fact that in these mice the IL-4 producer $\mathrm{CD}^{+}{ }^{+}$subset (namely Th-2 cells) seems to be responsible for the allogeneic stimulation of donor B cell (24) also argues against this possibility, because this particular $T$ cell subset does not seem to be susceptible to the same down-regulation mechanisms as the IL-2 producer Th-1 cells (32). These re-ınjection experiments indicate that, in the neonatally injected host, immunocompetent helper $T$ cells specific for alloantigens persist or are newly produced. In the thymus of 1 week old neonatally injected mice, we have recently shown an absence of specific $T$ helper alloreactivity against the tolerogen, with normal response to third party $\mathrm{H}-2$ disparate stimulator cells (21). Conversely, a high specific $T$ helper alloreactivity was detected in the spleens of these mice. All these observations strongly suggest that host alloreactive memory helper $T$ cells could be responsible for the activation of donor $\mathrm{B}$ cells re-injected in parental neonatally injected mice.

Nevertheless, a question still remains unsolved: why do these alloreactive $T$ cells not activate the small resting donor $B$ cell population in spleens of $F_{1}$ cell injected mice with self-limited autoimmune disease? One can argue that the very low number of donor $\mathrm{B}$ cells present in adult non-autoimmune tolerant mice (undetectable by flow cytometry) could be insufficient to interact with the host $\mathrm{T} \mathrm{CD}^{+}$cells. An increase in the number of donor $B$ cells, after their re-injection in neonatally injected non-autoimmune mice, could then potentiate this interaction. In any case, additional mechanisms of cellular control cannot be excluded, although the rapid disappearance of donor T cells from host lymphoid organs, when autoantibodies are still elevated, seems to exclude these cells in such a control mechanism, being consistent with the previously suggested view that donor $T$ cells play no significant role in this model (8).

\section{Acknowledgements}

This work has been supported by grants nos 88/1507 and 89/0365 from the 'Fondo de Investıgación Sanitaria', Minısterio de Sanidad, Spain. A. de la H. was the recipient of a grant (no. SAL90/0641) from the 'Comisión Interministerial de Ciencia y Tecnologia', Ministerio de Educación, Spain. The Basel Institute for Immunology is founded and supported by F. Hoffmann-La Roche Ltd, Basel, Switzerland. We thank Drs Ramón Merino and Stephane Schurmans (University of Geneva) and 


\section{Self-limited autoimmunity in neonatally injected mice}

Drs Francisco Leyva-Cobián and Jose Luis Fernández Luna (Hospital Universitario Marqués de Valdecilla, Santander) for helpful and stmulating discusstons; Mr G. Brighouse (University of Geneva) for providing us with bovine conglutinın; and María Jose Novo and Monserrat González for their technical assistance.

\section{Abbreviations}

$\begin{array}{ll}\text { AP } & \text { alkaline phosphatase } \\ \text { CIC } & \text { circulating immune complex } \\ \text { GMN } & \text { glomerulonephritis } \\ \text { LPS } & \text { lipopolysaccharide } \\ \text { SLE } & \text { systemic lupus erythematosus } \\ \text { TU } & \text { titration units }\end{array}$

\section{References}

1 Theophilopoulos, A. N. and Dixon, F 1985. Murıne models of SLE Adv. Immunol. 37:269

2 Andrews, B S., Eisenberg, R. S. Theophilopoulos, A N., Izui, S. Wilson, C B., McConahey, P.J., Murphy, E. D, Roths, J. B, and Dixon, F. J. 1978. Spontaneous munne lupus-like syndromes Clinical and immunopathological manfestations in several strans. J. Exp Med. $148 \cdot 1198$

3 Goldman, $M$, Feng, $H M$, Engers, $H$., Hochman, A., Louls, $J$, and Lambert, $P H$ 1983. Autormmunity and immune-complex disease after neonatal induction of transplantation tolerance in mice. $J$ Immunol. 131.251.

4 Luzuy, S., Merıno, J , Engers, H., Izui, S., and Lambert, P. H. 1986. Autoimmunity after induction of neonatal tolerance to alloantigens role of $\mathrm{B}$ cell chimerism and $\mathrm{F}_{1}$ donor $\mathrm{B}$ cell activation. J. Immunol. $136 \cdot 4420$.

5 Merıno, J, Schurmans, S., Luzuy, S., Izui, S., Vassallı, P. A, and Lambert, P. H 1987. Autormmune syndrome after induction of neonatal tolerance to alloantigens Effects of in vivo treatment with anti-T cell subset monoclonal antibodies. J. Immunot. 139.1426.

6 Menno, J A Alonso, J. L, Ramos, A, Gonzalez A, Rodriguez-Valverde, $V$, and De la Hera, M. 1991 Depletion of CD8 ${ }^{+}$T cells does not modify the evolution of the autommune syndrome observed in mice neonatally tolerized to alloantigens Allergy Immunol. (Life Sci. Ads), 9.227

7 Merıno, J., Schurmans, S., Duchosal, M., Izui, S, and Lambert, P. H 1989. Autommune syndrome after induction of neonatal tolerance to alloantigens $\mathrm{CD}^{+}{ }^{+} \mathrm{T}$ cells from the tolerance host activate autoreactive $F_{1} B$ cells. J. Immunot. 143:2202

8 Merino, J , Schurmans, S., Wen, L., Brighouse, G Luzuy, S, and Lambert, P. H. 1990. Autoimmune syndrome after induction of neonatal tolerance to alloantigens: analysis of the role of donor $T$ cells in the induction of autoimmunity. Cln Exp. Immunol. 79.273.

9 Hoffman, R. W. Alspaugh, M. A., Waggie, K. S., Durham, J. B., and Walker, S. E. 1984. Sjogren's syndrome in MRL $\pi$ and MRL/n mice. Arthntis Rheum 27:157.

10 Hang. L. M., Theophilopoulos, A. N., and Dixon, F. J. 1982 A spontaneous rheumatoid arthrits-like disease in MRL/ mice. $J$ Exp. Med. 155:1690

11 Berden, J. H. M., Hang, L. M., McConahey, P. J., and Dixon, F. J. 1983. Analysis of vascular lesions in murine SLE J Immunol. 130:1699.

12 Gleichmann, E., Pals, S. T., Rolink, A. G., Radaszkuewick, T., and Glerchmann, H. 1984. Graft-versus-host reactions: clues to the etiopathology of a spectrum of immunological diseases. Immunol. Today 5:324
13 Lieberman, R 1978 Genetrcs of lg CH (allotype) locus in the mouse Springer Semin. Immunopathot. 1:7.

14 Avrameas, S. 1969. Coupling of enzymes to proteins with glutaraldehyde Use of the conjugates for the detection of the antibodies. Immunochemistry 6.43 .

15 Maire, M. A., Barnet, M, and Lambert, P. H. 1981. Purification of bovine conglutunin using pepsin digestion Mol. Immunol. 18.85

16 Bancroft, J and Stevens, A. 1977. In Bancroft, J., ed., Theory and Practice of Histological Techniques. Churchill Livingston, New York.

17 Coffman, R and Weissman, 1. 1981 A monoclonal antıbody that recognizes $B$ cells and $B$ cell precursors in mice. J Exp. Mod 153.269

18 Kung. J., Sharrow, S., Seikmann, D., Liebermann, R., and Paul, W 1981. A mouse IgM allotypic determinant (Igh-6.5) recognized by a monoclonal rat antibody. J. Immunol. 127.873

19 Nishıkawa, S., Sasaki, Y., Kına, T., Amagai, T., and Katsura, T 1986 A monoclonal antubody against Igh 64 determinant. Immunogenetics 23:137

20 Oiu, T., Jones, P. P., Goding, J W, and Herzenberg, L A 1978. Properties of monoclonal antibodies to mouse $\mathrm{lg}$ allotypes, $\mathrm{H}-2$ and la antigens Curr Top. Microbiol. Immunol. 81.115

21 Schurmans, S., Brighouse, G., Kramar, G., Wen, L., Izul, S., Merno, J. and Lambert, P. H. 1991 Transient $T$ and $B$ cell activation after neonatal Induction of tolerance to $\mathrm{MHC}$ class II or Mls alloantigens. $J$ Immunol. 146.2152.

22 Martinez-A , C and Coutinho, A. 1981 B cell activation by helper cells is a two step process. Nature 290.60.

23 Powell, T J. and Strentein, J W 1990. Neonatal tolerance induction by class II alloantigens activate IL-4-secreting, tolerogen-responsive $T$ cells $J$ Immunot 144:854

24 Schurmans, S, Heuser, C, Qin, H.-Y., Mernno, J., Brighouse, G., and Lambert, P H 1990. In vivo effects of anti-IL-4 monoclonal antibody on neonatal induction of tolerance and on an associated autommune syndrome. J. Immunot. 1452465.

25 Hoffeld, J. T., Marrack, P, and Kappler, J. W. 1976 Antıgen-specific and nonspecific mediators of $T$ cell/B cell cooperation IV. Development of a modet system demonstrating responsiveness of two T cell functions to HGG in vitro $J$ Immunol 1171953

26 Sprent, J 1978 Restricted helper function of F1 hybrid T cells positively selected to heterologous erythrocytes in irradiated parental strain mice: II. Evidence for restrictions affecting helper cell induction and $\mathrm{T}-\mathrm{B}$ collaboration, both mapping to the Kend of the $\mathrm{H}-2$ complex J Exp. Med 1471159.

27 Schurmans, S., Merno, J., Qin, H.-Y., Kramar, G, Duchosal, M , Skallı, O., Benzonana, G, Gabbianı, G., and Lambert, P. H. 1991. Autoimmune syndrome after neonatal induction of tolerance to alloantigens' analysis of the specificity and of the cellular and genetic orıgin of autoantıbodies Autoimmunity 9283.

28 Dighıero, G., Lymberı, P., Holmberg, D., Lundquist, I., Coutinho, A., and Avrameas, S. 1985. High frequency of natural autoantibodies in normal newborn mice J. Immunot. $134 \cdot 765$

29 Holmberg, D., Forsgren, D., Ivars, F., and Coutinho, A. 1984. Reactions among lgM antibodies derived from normal, neonatal mice Eur. J. Immunol. 14:435.

30 Mueller, D. L., Jenkins, M. K, and Schwartz, R. H. 1989. Clonal expansion versus clonal inactivation Annu Rev Immunot 7.445.

31 Speiser, D. E , Brândle, R., Lees, R. K., Schneider, R., Zinkernaged, R M., and MacDonald, R. H. 1991. Neonatal tolerance to Mls-1 ${ }^{8}$ determinants. detection or anergy of $V_{g} 6^{+} T$ lymphocytes depending upon MHC compatibility of neonatally injected cells. Int. Immunol. 3.127.

32 Gilbert, K. M., Hoang, K. D, and Wiegle, W. O. 1990. Th1 and Th2 clones differ in their response to a tolerogenic signal $J$ Immunol. 144:2063. 